\title{
Physiological alterations and enzymatic evaluation of soybean cultivars under water deficit
}

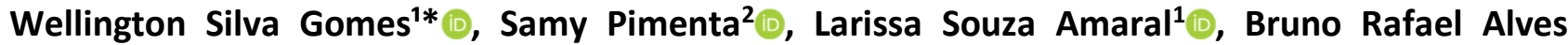 \\ Rodrigues $^{2}(-)$, Aluízio Borém ${ }^{3}(1)$
}

${ }^{1}$ State University of Minas Gerais - UEMG, Frutal, MG, Brazil. ${ }^{2}$ State University of Montes Claros - UNIMONTES, Janaúba, MG, Brazil. ${ }^{3}$ Federal University of Viçosa - UFV, Viçosa, MG - Brazil. * Corresponding author: wellington.gomes@uemg.br

\begin{abstract}
Drought is one of the main abiotic factors limiting agricultural productivity, capable of having a major impact on the yield of most crops. The knowledge of the physiological and biochemical mechanisms that differentiate resistance and susceptibility to water deficit among soybean strains can be used in the generation of more tolerant cultivars. In this sense, the objective of this study was to characterize physiologically, two soybean cultivars with different patterns of tolerance to drought in the field, by determining photosynthetic rates, lipid peroxidation levels and antioxidant enzyme activity under three levels of water potential. Upon reaching the V4 development stage, the irrigation of the plants was suspended and three data collection were performed: full irrigation (control); moderate water deficit $(\Psi=-$ $1.5 \pm 0.2 \mathrm{MPa})$ and severe deficit $(\Psi=-3.0 \mathrm{MPa} \pm 0.2 \mathrm{MPa})$. Variations in perspiration rate, stomatal conductance, as well as decrease in photosynthetic rate were significant between the two cultivars, where the water potentials in cultivar BR 16 anticipated on average two days achieving the same water potentials in Embrapa 48 cultivar, thus presenting better efficiency in water use. In addition, the increased activity of enzymes and lipid peroxidation were more significant in the cultivar BR 16, demonstrating that this cultivar is less tolerant to drought than Embrapa 48 cultivar, corroborating to agronomic data previously found in the field.
\end{abstract}

Keywords: Glycine max, hydric stress, physiological adjustments, stomatal conductance, drought, oxidative stress.

\section{INTRODUCTION}

Soybean plants are affected by various abiotic stresses such as high salinity, low temperatures, mineral element toxicity, drought and others (Ferreira et al., 2020; Escalera et al., 2021; Gontijo et al., 2021; Pimentel et al., 2021). Drought or continuous water deficiency is one of the most important factors affecting growth, development, survival and productivity of the crop (Manavalan, Guttikonda, Tran, \& Nguyen, 2009; Fried, Narayanan, \& Fallen, 2019). According to Food and Agriculture Organization of the United Nations (FAO) (2015) the international research community should be aware to solutions that reduce the problems caused by abiotic factors in agriculture, including drought. They also suggest that one of the possible solutions is the development and use of new plant cultivars.

Therefore the development of new cultivars tolerant to abiotic stresses, particularly to water stress, has a greater importance in soybean breeding programs. There are several studies related to this feature in Soybean, useful for these programs and for this purpose (Mwenye, Rensburg, Biljon, \& Merwe, 2018; Fried et al., 2019; Iqbal et al., 2019). Recently, the use of biotechnological tools has favored more detailed information involving the identification, interaction and quantification of genes involved in Soybean water deficit tolerance (Langridge \& Reynolds, 2015; Cilliers, Heerden, Kunert, \& Vorster 2018; Khan et al., 2018; Ye et al., 2020).

Plant physiological responses to drought are of physiological, biochemical, morphological and molecular in nature, and include stomatal closure, decreased photosynthetic activity, alteration of the cell wall elasticity, membrane fluidity and generation of toxic metabolites causing the death of the plant (Ramírez, Querejeta, \& Bellot, 2009). According to Xu et al. (2018) there are a large number of differentially expressed genes and the various pathways indicate that soy uses complex mechanisms to handle drought. However, they claim that some identified genes and pathways can be used in soybean breeding tolerant to water stress. It is therefore important to elucidate the processes occurring in plants under such conditions. 
Many of the deleterious processes supported by plants under water stress conditions are mediated by reactive oxygen species (ROS). The production of ROS can trigger the lipid peroxidation process in cell membranes, forming lipid hydroperoxides that lead to decreased fluidity, modifications of ionic permeability and other membrane-associated functions, thus being one of the most significant events of oxidative stress (Anjum et al., 2015; Anjum et al., 2017).

To reduce the damage caused by ROS, efficient enzymatic and non-enzymatic antioxidant defense systems act in a coordinated manner under stressful conditions in order to maintain intracellular homeostasis. The enzymes ascorbate peroxidase (APX), Glutathione peroxidase (GPX), catalase (CAT), Glutathione reductase (GR) and phenol peroxidase (POX), subsequently detoxify $\mathrm{H}_{2} \mathrm{O}_{2}$ by releasing $\mathrm{H}_{2} \mathrm{O}$ by different oxidation processes (You \& Chan, 2015).

Understanding how plants respond to water deficit and understanding tolerance mechanisms is critical to predicting impacts on crop production and is currently one of the largest research topics for the development of more tolerant and productive cultivars. Thus, the physiological characterization may be an important and fast procedure to select different cultivars that in the same experimental condition may show different levels of tolerance to stress (Atkin \& Macherel, 2009).

Within this context, the present study aimed at characterizing physiologically two conventional soybean cultivars, contrasting for drought tolerance, in order to better understand the mechanisms of response to this tolerance.

\section{MATERIALS AND METHODS}

\section{Plant material, cultivation conditions and experimental design}

The experiment was conducted in the greenhouse of the Molecular Physiology Laboratory of the Federal University of Viçosa, during the year of 2016, under partially controlled conditions with average temperatures of $25^{\circ} \mathrm{C}$ and $60 \%$ humidity, with a variation of up to $15 \%$ more or less. Embrapa 48 and BR 16 soybean cultivars were selected because they present contrasting responses in the field when submitted to periods of water deficit, and the Embrapa 48 being considered the most tolerant to drought (Texeira et al., 2008).

The experimental design adopted was completely randomized with a $2 \times 3$ factorial scheme $(2$ cultivars $\times 3$ water treatments), with five replications. The experimental unit consisted of one pot containing $6.5 \mathrm{~kg}$ of substrate / pot with $50 \%$ vermiculite and $50 \%$ washed coarse sand composition, and two plants of each cultivar, totaling 30 pots for the entire experiment.

After the emergence of the fully developed fourth trifoliate, irrigation was suspended and the cultivars were subjected to two water deficit levels, with daily measurements between 05:00am and 06:00am o'clock. The first level was considered moderate water stress, with water potential of $\Psi_{\mathrm{W}}=-1.5 \mathrm{Mpa}$. The second, as severe water stress, $\Psi_{\mathrm{W}}=-3.0 \mathrm{Mpa}$. The water potential of each plant was measured in a Scholander pressure chamber. For these evaluations, a third node leaf was used. For this, two leafs of each plant was used to water system adopted. Fourth node leaf collections were performed up to 12 days after the application of the water deficit condition for further physiological analysis.

\section{Evaluation of physiological characteristics}

Gas exchange determinations were performed with a portable photosynthesis meter, IRGA; portable model LI-6400xt, LI-COR Biosciences Inc., Lincon, Nebraska, USA. Measurements were always made in the median area of the fully expanded leaves, totally exposed to solar radiation in the period from 08: 30am to 10: $00 \mathrm{o}^{\prime}$ clock. The following characteristics were measured: photosynthetic rate (A) $\left(\mu \mathrm{mol} \mathrm{m} \mathrm{m}^{-2} \mathrm{~s}^{-1}\right)$; leaf transpiration rate (E) (mmol m $\left.\mathrm{m}^{-2} \mathrm{~s}^{-1}\right)$; stomatal conductance on leaves (Gs) (mol m $\left.\mathrm{m}^{-2} \mathrm{~s}^{-1}\right)$ and $\mathrm{CO}_{2}$ concentration in the intercellular spaces (A) $\left(\mathrm{mmol} \mathrm{m}^{-2} \mathrm{~s}^{-1}\right)$.

The level of membrane lipid peroxidation in leaf tissues was measured in terms of the malondialdehyde content formed (MDA, a lipoperoxidation product), determined by the thiobarbituric acid reaction (TBA) according to the method described by Gomes-Junior et al. (2006).

Ascorbate peroxidase activity (APXs) (EC 1.11.1.11) was determined by the method of Nakano and Asada (1981), by monitoring the oxidation rate of ascorbate at $290 \mathrm{~nm}$ at $28^{\circ}$ C. Catalase activity (CATs) (EC 1.11.1.6.) was determined according to Peixoto, Cambraia, Sant'Anna, Mosquim, \& Moreira, (1999) by monitoring the decrease in absorbance at $240 \mathrm{~nm}$ at $28^{\circ} \mathrm{C}$. Glutathione reductase (GR) activity (EC 1.6.4.2) 
was determined according to Queiroz, Alonso, Mares-Guia and Magalhaes (1998). NADPH oxidation was obtained by monitoring the decrease in absorbance at $340 \mathrm{~nm}$ at $28^{\circ} \mathrm{C}$. The activity of peroxidases (POX) (EC 1.11.1.7) was determined by the method of Kar and Mishra (1976) by increasing the absorbance at $420 \mathrm{~nm}$, at $28^{\circ} \mathrm{C}$ and, superoxide dismutases activity (SODs) (EC 1.15.1.1) was determined according to Longo, González, Pastori and Trippi (1993) by increasing the absorbance of the samples to $560 \mathrm{~nm}$.

\section{Statistical analysis}

The data obtained was submitted to presuppositions based on normality and homogeneity of residual variances. After, the characters were submitted to variance analysis of $5 \%$ probability by $\mathrm{F}$ test. Afterwards the analysis of variance was carried out in order to identify significant interaction between treatments and cultivars, these significant were dismembered and significant differences between treatments were detected using the Tukey mean test $(p<0.05)$.

The relationship between treatments was evaluated by multivariate analysis, and the main components (ACP) were obtained from MDA data and antioxidant enzymes. The grouping of the treatments was done by Tocher's methodology. The variables were analyzed using R software 3.5.2 version (R Core Team, 2018), with the aid of Cluster, RCMDR and Ade4 packages (Dray et al., 2018).

\section{RESULTS AND DISCUSSION}

According to the classification of experimental precision (coefficient of variation "CV\%") proposed by Gomes (1990), the values found for the experiments of physiological parameters and activity of antioxidant enzymes, obtained a medium experimental precision ( $10.7 \%$ and $20.02 \%$, respectively), which is favorable, as it strongly attests to the inferences raised. The days after the suspension of irrigation experiment showed a low experimental precision ( $\mathrm{CV} \%=33.96)$. The high $\mathrm{CV} \%$ can be explained by the fact that it is a variable determined by a quantitative characteristic, determined by many genes, as there is a high environmental influence. One way to reduce this effect is to increase the number of repetitions in the experiment and also opt for more rigid experimental designs, in order to mitigate the environmental influence.

After water restriction, it was observed that the cultivars reached moderate and severe water potentials at different times, and the tolerant cultivar had longer time to reach these water potentials. The cultivar Embrapa 48 required two days longer than the cultivar BR 16, indicating that this cultivar is more tolerant to drought (Figure 1).

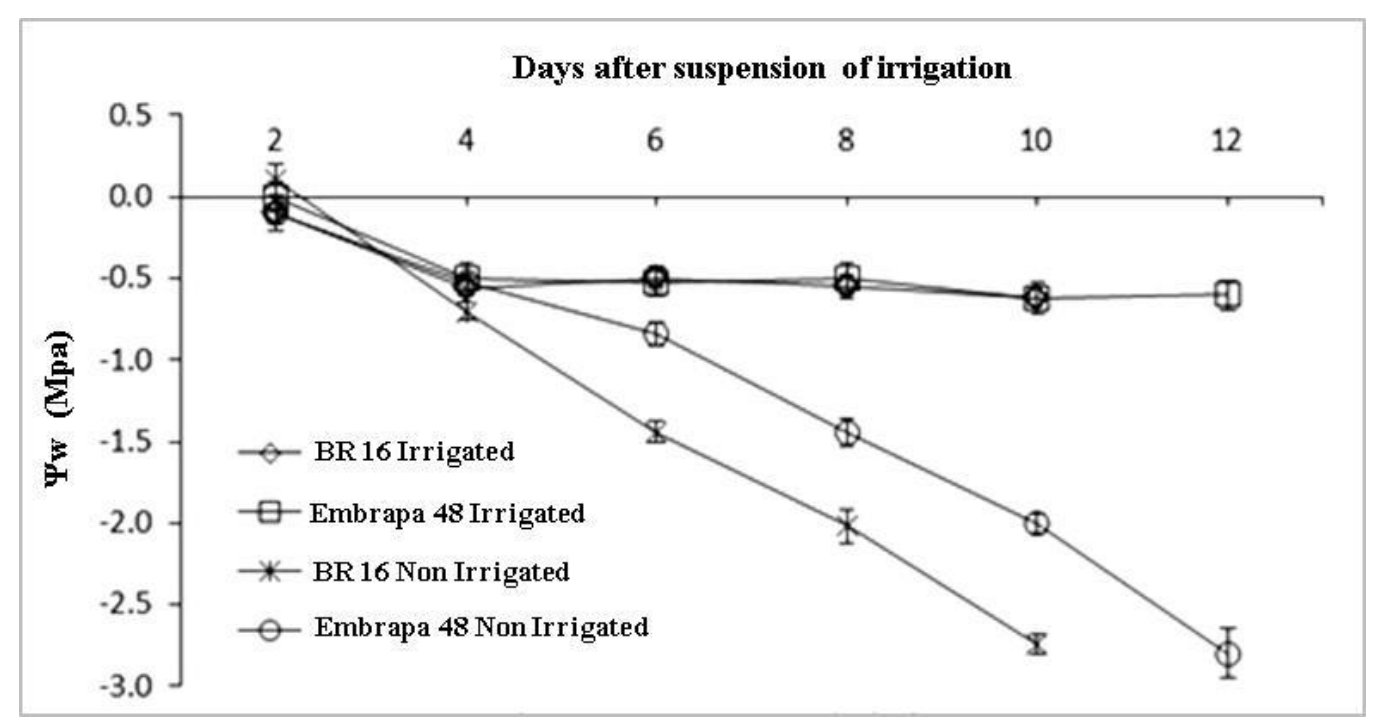

Figure 1. Days after the suspension of irrigation for the cultivars BR 16 and Embrapa 48 to reach the severe water potential $\left(\Psi_{\mathrm{W}}\right.$ of $\left.-3.0 \mathrm{Mpa}\right)$. Error bars correspond to the standard deviation of the mean.

Several effects due to water deficit have been reported in plants, such as increased stomatal resistance, reducing leaf transpiration leading to lower $\mathrm{CO}_{2}$ availability for photosynthesis (Zhou, Lam, \& Zhang, 2007). In the present study, photosynthetic and transpiratory rates, as well as stomatal conductance decreased 
significantly in relation to irrigated treatment among cultivars (Figure 2). These effects ultimately reduce the productivity of various crops such as Alfalfa (Medicago sativa L.) (Liu, Wu, Ge, Han, \& Jia, 2018); Sunflower (Helianthus annuus L.) (Hussain, et al., 2018) and Soybean (Glycine max) (Sabagh et al., 2018; Gavili, Moosavi, \& Haghighi, 2019).

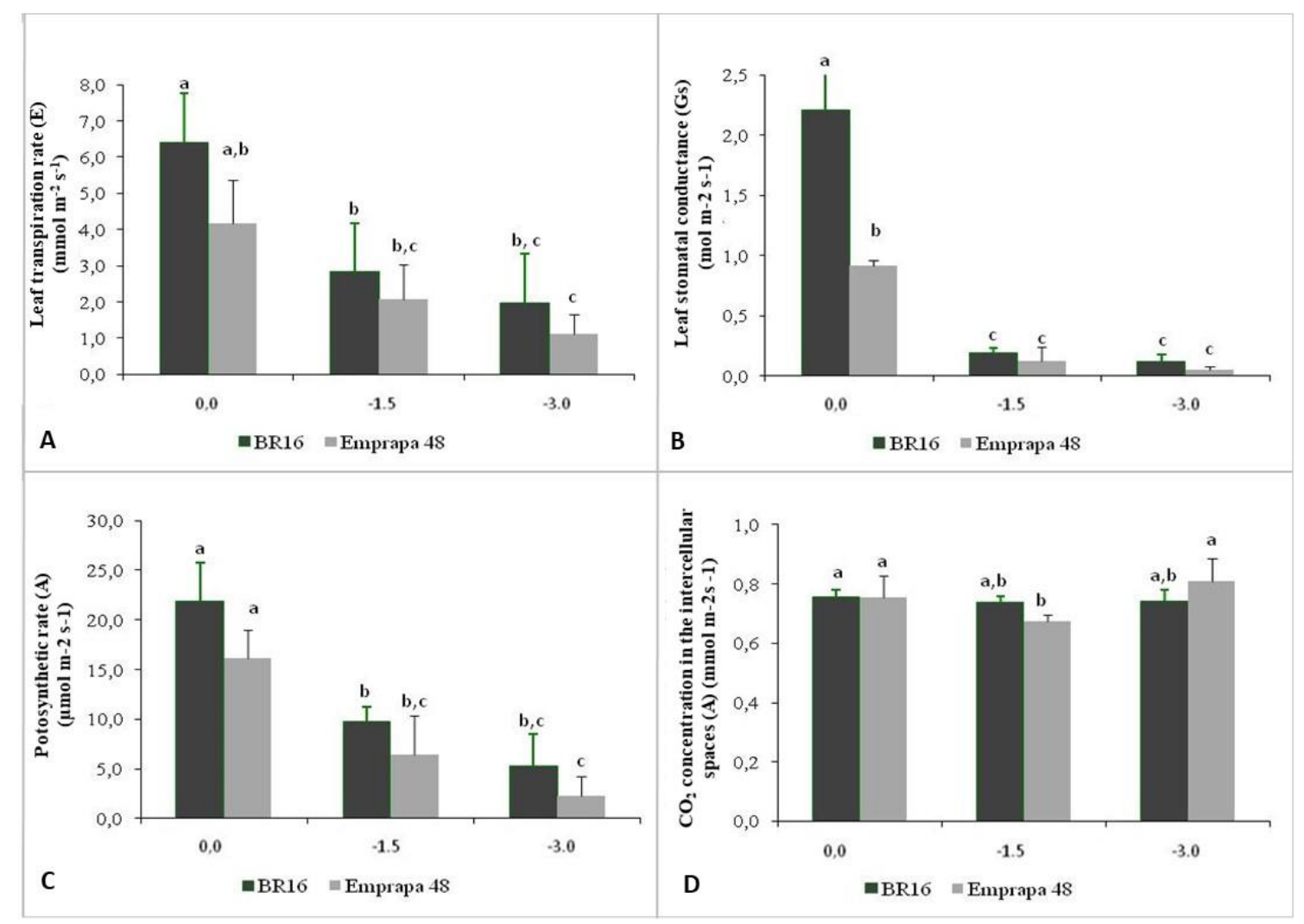

Figure 2. Average values of physiological parameters: A - leaf transpiration rate $(E)$, B - stomatal conductance on leaves (Gs), C - photosynthetic rate (A), D - $\mathrm{CO}_{2}$ concentration in the intercellular spaces $(A)$, in two soybean cultivars, submitted to three levels of water potential. Different letters indicate significant difference between cultivars by Tukey test $(p<0.05)$. Error bars correspond to the standard deviation of the mean.

Although the dehydration curve shows that the cultivar Embrapa 48 delayed dehydration at different water deficit levels, in the absence of stress, there were no significant differences between cultivars (Figure 2). Showing that under irrigated conditions the plants have similar physiological profiles. In addition, the tolerant cultivar had lower leaf water potential the day before the experiment, In addition, the tolerant cultivar had a lower leaf water potential the day before the experiment, which may be explained by the higher stomatal conductance and transpiration rate, suggesting that the tolerant cultivar had higher hydraulic conductivity. According to Gray et al. (2016) the combined effects on stomatal conductance, with factors such as temperature, in soybean may not change yield under different $\mathrm{CO}_{2}$ fertilization conditions, and higher doses of $\mathrm{CO}_{2}$ are not advantageous. It is proposed that during drought years, reduced stomatal conductance will ease the increased vapor pressure deficit in transpiration helping to preserve crop yield (Gorthi, Volenec, \& Welp, 2019).

Except for the intercellular concentration of $\mathrm{CO}_{2}$, the differences found were due to the level of water restriction imposed, as well as by the cultivar. Transpiration rate, stomatal conductance and photosynthesis rate were strongly affected by water restriction levels and the increase in water potential induced a decrease in the real value of the measured variables. It is noteworthy that the largest variations were identified in cultivar BR 16, while Embrapa 48 showed greater resistance to the decrease of the parameters mentioned.

The non-significance of the values for the ratio between internal and external $\mathrm{CO}_{2}$ concentrations $(\mathrm{Ci} / \mathrm{Ca})$ indicates that the decrease in photosynthesis rate was due to increased stomatal resistance and also to the effect of water stress on photosynthesis. The gradual decrease of photosynthesis was smaller in the tolerant cultivar under moderate deficit, which may indicate inhibition of the most intense biochemical or 
photochemical phase in the sensitive genotype. According to Iqbal et al. (2019) the reduction of photosynthesis results in the reduction of $\mathrm{CO}_{2}$ diffusion in leaves due to lower internal and stomatal conductance.

The photosynthetic rate decreased from $55 \%$ and $95 \%$ in moderate and severe water potentials for cultivar BR 16, while in Embrapa 48 for the same water potentials, the rates were $15 \%$ and $78 \%$. The transpiration rate and stomatal conductance parameters also have similar patterns, since these parameters directly affect the photosynthetic rate. In this sense, it is assumed that the cultivar Embrapa 48 can tolerate more the imposition of water stress in relation to cultivar BR 16, maintaining higher photosynthesis levels under the same water potentials.

The gradual decrease of photosynthesis was smaller in the tolerant cultivar under the two water deficit levels, with differences in stomatal conductance, which may indicate inhibition of the most intense biochemical or photochemical phase in the sensitive genotype. The drastic reduction in stomatal conductance identified in cultivar BR 16 may possibly have led to decreased consumption of electrons released from water, causing excess energy that reacts with oxygen, causing oxidative stress and initiating the process of lipid peroxidation in cell membranes and detoxification by antioxidant enzymes (Apel \& Hirt, 2004; Guo, Tian, Liu, Wang, \& Sui, 2018).

The higher tolerance to drought of cultivar Embrapa 48 can also be verified in lipid peroxidation (MDA) rates. Although both cultivars have increased oxidative damage with the imposition of water stress, it was always higher in tolerant leaves in all treatments. Overall, the increase in MDA levels was proportional to the level of stress imposition (Figure $3 \mathrm{~A}$ ). For the water potential level $\psi \mathrm{ma}=-1.5 \mathrm{Mpa}$, the increase was greater in BR 16 (106\%), while in Embrapa 48 the increase was only 56\%. Several studies illustrate the increase in lipid peroxidation under water stress: in Sweet corn (Zea mays) (Terzi, Güler, Güven, \& Kadioglu, 2018); Rice (Oryza sativa) (Qureshi et al., 2018; Gorthi et al., 2019) and Sorghum (Sorghum bicolor) (Guo et al., 2018).

The increase in activity of antioxidant enzymes was higher for the water potential $\Psi=-1.5 \mathrm{MPa}$, compared to the irrigated one. In cultivar BR 16 the increase in enzyme activity was greater than the variation identified in Embrapa 48. In the first cultivar, the increase rates were 71\% for GR enzyme, 73\% for SOD, $57 \%$ for CAT, $90 \%$ for APX and $123 \%$ for POX. In the cultivar Embrapa 48 the increase was $19 \%$ for $24 \%$ GR, $20 \%$ for SOD, $33 \%$ for CAT, $14 \%$ for APX and $64 \%$ for POX, in relation to the rates found in irrigated treatments (Figure 3).

The consequences of the ideal lack of water are oxidative stress and reduced photosynthetic characteristics (Guo et al., 2018). Oxidative stress stimulates biosynthesis of antioxidant components and increases the activity of antioxidant enzymes. However, some species or cultivars may have greater resistance to this stress, contributing to a less pronounced increase than in other plants. Its concentrations and activities are related to many physiological processes involved in cellular signaling mechanisms in plant defense or oxidative stress (Soares \& Machado, 2007).

Thus, the higher antioxidant activity in cultivar BR 16 can be explained by the fact that it has a lower ability to drain excess of reducing power from oxidative stress such as photorespiration, membrane peroxidation, cyclic electron flow in the thylakoid, among others. Therefore, a significantly larger increase is needed to counteract the effects of drought-induced oxidative stress (Scheibe, Backhausen, Emmerlich, \& Holtgrefe, 2005; Heber, 2008).

It was observed, with the study of the similarity pattern between cultivars, that the first two main components explained approximately $97.34 \%$ of all observed variation, which allowed the dispersion of treatments in the Cartesian plane quite reliably (Figure 4). It was found that the most similar treatments were grouped according to the imposition of water stress.

The six treatments were associated in three distinct groups. Group I formed by the irrigated treatments. Group II by Embrapa 48 in the two levels of stress imposition and Group III formed by the two treatments in BR 16. In conclusion, regardless of cultivar, in the absence of water stress, both cultivars respond in a similar way. On the other hand, for the other two stress levels, $(\psi \mathrm{ma})=-1.5 \mathrm{Mpa}$ and $(\psi \mathrm{ma})=-3.0 \mathrm{Mpa}$, the grouping was dependent on the cultivar, so stress imposition varied within each cultivar and was not similar for the same level of water stress in the different cultivars. 


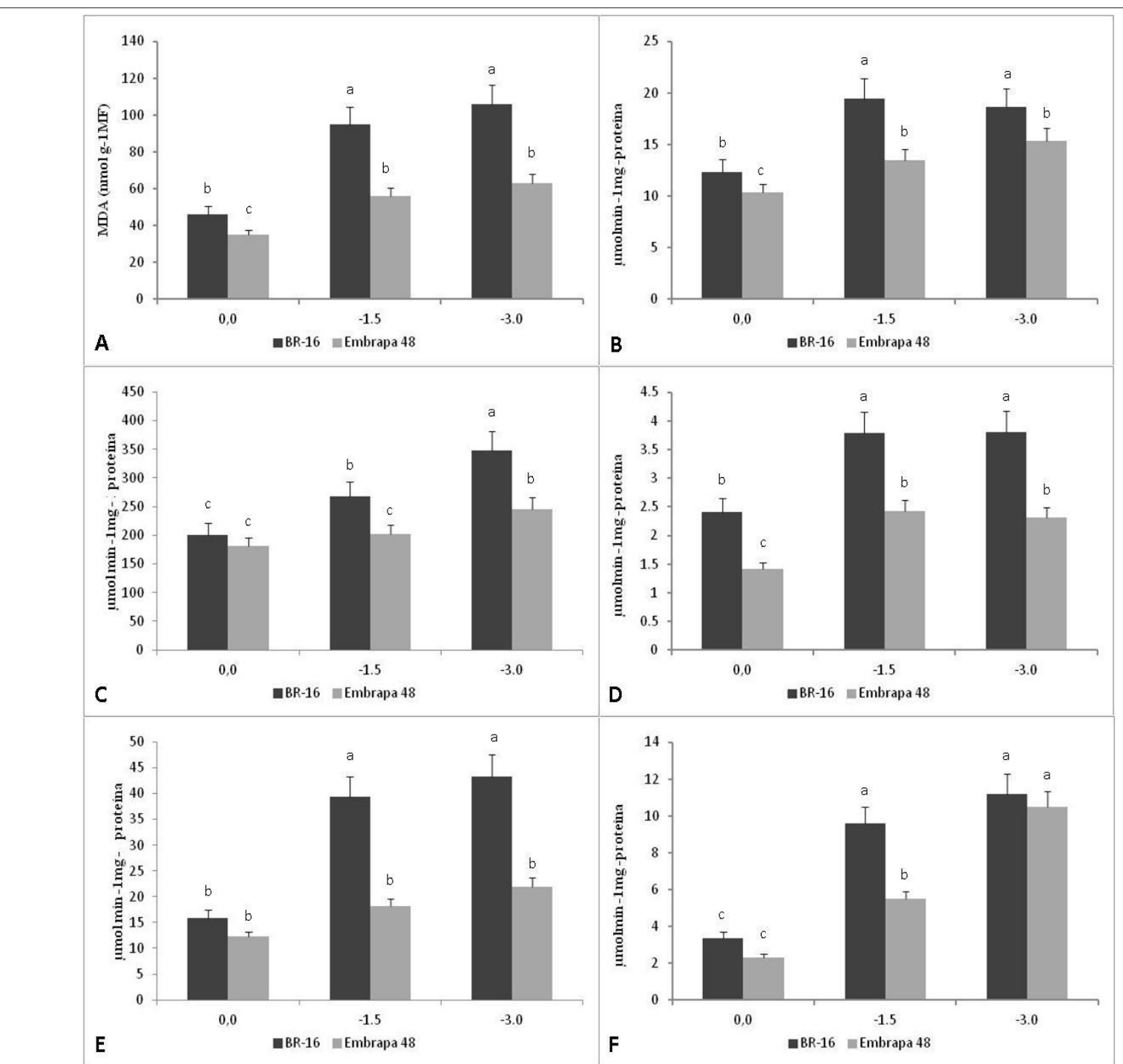

Figure 3. Effect of water deficit imposition on lipid peroxidation and on the activity of antioxidant enzymes in two soybean cultivars. submitted to three levels of water potential. A- lipid peroxidation (MDA) rates, Bglutathione reductase, C- superoxide dismutases, D- catalase, E- ascorbate peroxidase e F- peroxidases, Different letters indicate significant difference between cultivars by Tukey test $(p<0.05)$. Error bars correspond to the standard deviation of the mean.

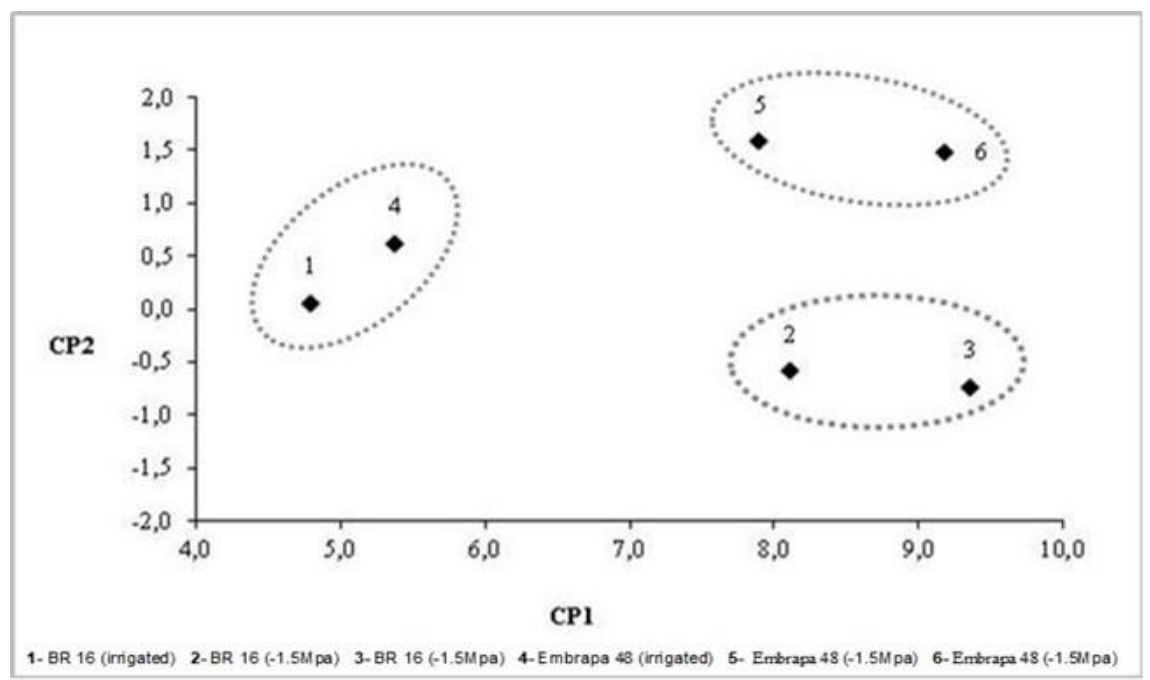

Figure 4. Dispersion of the main components from the malondialdehyde and the five antioxidant enzymes analyzed. Treatments: 1- BR 16 irrigated $(\psi \mathrm{m}=0.0 \mathrm{Mpa}), 2-B R 16$ in moderated water stress $(\psi \mathrm{m}=-1.5 \mathrm{Mpa})$, 3BR-16 in severe stress $(\psi \mathrm{m}=-3.0 \mathrm{Mpa}), 4-$ Embrapa 48 irrigated $(0.0 \mathrm{Mpa}), 5-$ Embrapa $48(-1.5 \mathrm{Mpa})$ and 6Embrapa 48 (-3.0Mpa). The dotted markings represent the most similar groupings by Tocher's methodology. 


\section{CONCLUSIONS}

Both cultivars responded differently to the imposition of water stress on the physiological parameters analyzed. The cultivar Embrapa 48 proved to be more tolerant to this stress than the cultivar BR 16 . The data allowed us to suggest that such physiological parameters can be used in the evaluation and distinction of tolerant and water deficit sensitive soybean genotypes.

\section{ACKNOWLEDGEMENTS}

The authors thank the Fundação de Amparo à Pesquisa do Estado de Minas Gerais (FAPEMIG), Conselho Nacional de Desenvolvimento Científico e Tecnológico (CNPq) and Coordenação de Aperfeiçoamento de Pessoal de Nível Superior (CAPES), for their financial support and individual grants provided for the present study.

\section{REFERENCES}

Anjum, N. A., Sofo, A., Scopa, A., Roychoudhury, A., Gill, S. S., Iqbal, M., ... Ahmad, I. (2015). Lipids and proteins - major targets of oxidative modifications in abiotic stressed plants. Environmental Science and Pollution Research, 22(6), 4099-4121. https://doi.org/10.1007/s11356-014-3917-1

Anjum, S. A., Ashraf, U., Tanveer, M., Khan, I., Hussain, S., Shahzad, B., ... Wang, L. C. (2017). Drought induced changes in growth, osmolyte accumulation and antioxidant metabolism of three maize hybrids. Frontiers in Plant Science, 8(FEBRUARY), 1-12. https://doi.org/10.3389/fpls.2017.00069

Apel, K., \& Hirt, H. (2004). Reactive oxygen species: Metabolism, oxidative stress, and signal transduction. Annual Review of Plant Biology, 55, 373-399. https://doi.org/10.1146/annurev.arplant.55.031903.141701

Atkin, O. K., \& Macherel, D. (2009). The crucial role of plant mitochondria in orchestrating drought tolerance. Annals of Botany, 103(4), 581-597. https://doi.org/10.1093/aob/mcn094

Cilliers, M., Wyk, S. G., Heerden, P. D. R., Kunert, K. J., \& Vorster, B. J. (2018). Identification and changes of the drought-induced cysteine protease transcriptome in soybean (Glycine max) root nodules. Environmental and Experimental Botany, 148, 59-69. https://doi.org/10.1016/j.envexpbot.2017.12.005

Dray, S., Blanchet, G., Borcard, D., Clappe, S., Guenard, G., Jombart, T., Larocque, G., Legendre, P., Madi, N., Wagner, H.H. (2018). Adespatial: multivariate multiscale spatial analysis. R package version 0.2-0.

Escalera, R. A. V., Carvalho, I. R., Pimentel, J. R., Troyjack, C., Szareski, V. J., Jaques, L. B. A., ... Pedó, T. (2021). Nodulation and agronomic performance of soybean grown in different seeding periods and glyphosate formulations. Agronomy Science and Biotechnology, 7, 1-10. https://doi.org/10.33158/asb.r122.v7.2021

FAO - Food and Agriculture Organization of the United Nations. (2015). Towards a water and food secure future: critical perspectives for policy-makers. Rome, Italy. Retrieved from http://www.fao.org/home/en/

Ferreira, L. L., Ricardo Viana de Carvalho, P., Fernandes, M. de S., Silva, J. G., Ricardo Carvalho, I., \& Lautenchleger, F. (2020). Neural network and canonical interrelationships for the physiological aspects of soybean seedlings: effects of seed treatment. Agronomy Science and Biotechnology, 6, 1-11. https://doi.org/10.33158/asb.r116.v6.2020

Fried, H. G., Narayanan, S., \& Fallen, B. (2019). Evaluation of soybean [Glycine max (L.) Merr.] genotypes for yield, water use efficiency, and root traits. PLOS ONE, 14(2), 1-18. https://doi.org/10.1371/journal.pone.0212700

Gavili, E., Moosavi, A. A., \& Haghighi, A. A. K. (2019). Does biochar mitigate the adverse effects of drought on the agronomic traits and yield components of soybean? Industrial Crops and Products, 128(March 2018), 445-454. https://doi.org/10.1016/j.indcrop.2018.11.047 
Gomes, F. P. (1990). Curso de estatística experimental (12 ${ }^{\text {th }}$ ed.). Piracicaba, SP: Fealq.

Gomes-Junior, R. A., Moldes, C. A., Delite, F. S., Pompeu, G. B., Gratão, P. L., Mazzafera, P., ... Azevedo, R. A. (2006). Antioxidant metabolism of coffee cell suspension cultures in response to cadmium. Chemosphere, 65(8), 1330-1337. https://doi.org/10.1016/j.chemosphere.2006.04.056

Gorthi, A., Volenec, J. J., \& Welp, L. R. (2019). Stomatal response in soybean during drought improves leafscale and field-scale water use efficiencies. Agricultural and Forest Meteorology, 276-277(June 2018), 107629. https://doi.org/10.1016/j.agrformet.2019.107629

Gontijo, W. D. R., Sousa, P. H. S., Matsuo, É., Resende, J. C., Barros, P. H. F. C., \& Bomtempo, G. L. (2021). Epicotyl length in seedlings of soybean cultivars subjected to reduced inter-row spacing. Agronomy Science and Biotechnology, 7, 1-7. https://doi.org/10.33158/asb.r132.v7.2021

Gray, S. B., Dermody, O., Klein, S. P., Locke, A. M., McGrath, J. M., Paul, R. E., ... Leakey, A. D. B. (2016). Intensifying drought eliminates the expected benefits of elevated carbon dioxide for soybean. Nature Plants, 2(9), 1-8. https://doi.org/10.1038/nplants.2016.132

Guo, Y. Y., Tian, S. S., Liu, S. S., Wang, W. Q., \& Sui, N. (2018). Energy dissipation and antioxidant enzyme system protect photosystem II of sweet sorghum under drought stress. Photosynthetica, 56(3), 861872. https://doi.org/10.1007/s11099-017-0741-0

Heber, U. (2008). Photoprotection of green plants: A mechanism of ultra-fast thermal energy dissipation in desiccated lichens. Planta, 228(4), 641-650. https://doi.org/10.1007/s00425-008-0766-5

Hussain, M., Farooq, S., Hasan, W., Ul-Allah, S., Tanveer, M., Farooq, M., \& Nawaz, A. (2018). Drought stress in sunflower: Physiological effects and its management through breeding and agronomic alternatives. Agricultural Water Management, 201(February), 152-166. https://doi.org/10.1016/j.agwat.2018.01.028

Iqbal, N., Hussain, S., Raza, M. A., Yang, C. Q., Safdar, M. E., Brestic, M., ... Liu, J. (2019). Drought Tolerance of Soybean (Glycine max L. Merr.) by Improved Photosynthetic Characteristics and an Efficient Antioxidant Enzyme Activities Under a Split-Root System. Frontiers in Physiology, 10(July). https://doi.org/10.3389/fphys.2019.00786

Kar, M., \& Mishra, D. (1976). Catalase, Peroxidase, and Polyphenoloxidase Activities during Rice Leaf Senescence. Plant Physiology, 57(2), 315-319. https://doi.org/10.1104/pp.57.2.315

Khan, M. A., Tong, F., Wang, W., He, J., Zhao, T., \& Gai, J. (2018). Analysis of QTL-allele system conferring drought tolerance at seedling stage in a nested association mapping population of soybean [G/ycine $\max$ (L.) Merr.] using a novel GWAS procedure. Planta, 248(4), 947-962. https://doi.org/10.1007/s00425-018-2952-4

Langridge, P., \& Reynolds, M. P. (2015). Genomic tools to assist breeding for drought tolerance. Current Opinion in Biotechnology, 32, 130-135. https://doi.org/10.1016/j.copbio.2014.11.027

Liu, Y., Wu, Q., Ge, G., Han, G., \& Jia, Y. (2018). Influence of drought stress on afalfa yields and nutritional composition. BMC Plant Biology, 18(1), 1-9. https://doi.org/10.1186/s12870-017-1226-9

Longo, O. T., González, C. A., Pastori, G. M., \& Trippi, V. S. (1993). Antioxidant defences under hyperoxygenic and hyperosmotic conditions in leaves of two lines of maize with differential sensitivity to drought. Plant and Cell Physiology, 34(7), 1023-1028. https://doi.org/10.1093/oxfordjournals.pcp.a078515

Manavalan, L. P., Guttikonda, S. K., Tran, L. S. P., \& Nguyen, H. T. (2009). Physiological and molecular approaches to improve drought resistance in soybean. Plant and Cell Physiology, 50(7), 1260-1276. https://doi.org/10.1093/pcp/pcp082 
Mwenye, O. J., Rensburg, L., Biljon, A., \& Merwe, R. (2018). Seedling Shoot and Root Growth Responses among Soybean (Glycine max) Genotypes to Drought Stress. In In Soybean-Biomass. Yield and Productivity. London, UK: IntechOpen. Retrieved from https://www.intechopen.com/books/soybeanbiomass-yield-and-productivity/seedling-shoot-and-root-growth-responses-among-soybean-glycinemax-genotypes-to-drought-stress.

Peixoto, P. H. P., Cambraia, J., Sant'Anna, R., Mosquim, P. R., \& Moreira, M. A. (1999). Aluminum effects on lipid peroxidation and on the activities of enzymes of oxidative metabolism in sorghum. Revista Brasileira de Fisiologoia Vegetal, 11(3), 137-143. Retrieved from http://www.cnpdia.embrapa.br/rbfv/pdfs/v11n3p137.pdf

Pimentel, J. R., Carvalho, I. R., Troyjack, C., Junior, G. T., Szareski, V. J., Conte, G. G., ... Hutra, D. J. (2021). Water deficit in the soybean breeding. Agronomy Science and Biotechnology, 7, 1-20. https://doi.org/10.33158/asb.r128.v7.2021

Queiroz, C. G. S., Alonso, A., Mares-Guia, M., \& Magalhaes, A. C. (1998). Chilling induced changes in membrane fluidity and antioxidant enzyme activities in Coffea Arabica L. roots. Biologia Plantarum, 41(3), 403-413. https://doi.org/10.1023/A:1001802528068

Qureshi, M. K., Munir, S., Shahzad, A. N., Rasul, S., Nouman, W., \& Aslam, K. (2018). Role of reactive oxygen species and contribution of new players in defense mechanism under drought stress in rice. International Journal of Agriculture and Biology, 20(6), 1339-1352. https://doi.org/10.17957/IJAB/15.0640

Ramírez, D. A., Querejeta, J. I., \& Bellot, J. (2009). Bulk leaf $\delta 180$ and $\delta 13 C$ reflect the intensity of intraspecific competition for water in a semi-arid tussock grassland. Plant, Cell and Environment, 32(10), 1346-1356. https://doi.org/10.1111/j.1365-3040.2009.02002.x

$\mathrm{R}$ Core Team (2018). R: A language and environment for statistical computing. Vienna, Austria: $\mathrm{R}$ Foundation for Statistical Computing. Retrieved from https://www.r-project.org/

Sabagh, A. EL, Hossain, A., Islam, M. S., Barutcular, C., Fahad, S., Ratnasekera, D., ... Saneoka, H. (2018). Role of osmoprotectants and soil amendments for sustainable soybean (Glycine max L.) production under drought condition: A review. Journal of Experimental Biology and Agricultural Sciences, 6(1), 32-41. https://doi.org/10.18006/2018.6(1).32.41

Scheibe, R., Backhausen, J. E., Emmerlich, V., \& Holtgrefe, S. (2005). Strategies to maintain redox homeostasis during photosynthesis under changing conditions. Journal of Experimental Botany, 56(416), 1481-1489. https://doi.org/10.1093/jxb/eri181

Soares, A. M. S., \& Machado, O. L. T. (2007). Defesa de plantas : Sinalização química e espécies reativas de oxigênio Plant Defense: chemical signaling and reactive oxygen species. Revista Trópica - Ciências Agrárias e Biológicas, 1(1), 9-19.

Terzi, R., Güler, N. S., Güven, F. G., \& Kadioglu, A. (2018). Alpha lipoic acid treatment induces the antioxidant system and ameliorates lipid peroxidation in maize seedlings under osmotic stress. Archives of Biological Sciences, 70(3), 503-511. https://doi.org/10.2298/ABS171218011T

Texeira, L. R., Braccini, A. L. E., Sperandio, D., Scapim, C. A., Schuster, I., \& Viganó, J. (2008). Avaliação de cultivares de soja quanto à tolerância ao estresse hídrico em substrato contendo polietileno glicol. Acta Scientiarum - Agronomy, 30(2), 217-223. https://doi.org/10.4025/actasciagron.v30i2.1731

Xu, C., Xia, C., Xia, Z., Zhou, X., Huang, J., Huang, Z., ... Zhang, C. (2018). Physiological and transcriptomic responses of reproductive stage soybean to drought stress. Plant Cell Reports, 37(12), 1611-1624. https://doi.org/10.1007/s00299-018-2332-3

Ye, H., Song, L., Schapaugh, W. T., Ali, M. L., Sinclair, T. R., Riar, M. K., ... Nguyen, H. T. (2020). The importance of slow canopy wilting in drought tolerance in soybean. Journal of Experimental Botany, 71(2), 642-652. https://doi.org/10.1093/jxb/erz150 
You, J., \& Chan, Z. (2015). Ros regulation during abiotic stress responses in crop plants. Frontiers in Plant Science, 6(DEC), 1-15. https://doi.org/10.3389/fpls.2015.01092

Zhou, Y., Lam, H. M., \& Zhang, J. (2007). Inhibition of photosynthesis and energy dissipation induced by water and high light stresses in rice. Journal of Experimental Botany, 58(5), 1207-1217. https://doi.org/10.1093/jxb/erl291

Received: May 19, 2021.

Accepted: June 3, 2021.

Published: July 12, 2021.

\section{English by: Osmer Balam.}

